\title{
Susceptibility of seagrass to oil spills: a case study with eelgrass, Zostera marina in San Francisco Bay, USA
}

Gregory A. Piniak ${ }^{1,2}$, Mark Fonseca ${ }^{3}$, Natalie Cosentino-Manning ${ }^{4}$

Keywords: oil, seagrass, San Francisco Bay, Cosco Busan, eelgrass, Zostera marina, PAM 


\begin{abstract}
Existing literature illustrates inconsistent responses of seagrasses to oil exposure, both in the field and in the laboratory. Here, we add a new study that combined morphometric, demographic and photophysiology assessments to determine the potential oiling impacts to eelgrass (Zostera marina) from the 2007 Cosco Busan event in San Francisco Bay. Shoot densities, reproductive status, and rhizome elongation of Z. marina were examined at sites with pre-spill data, and eelgrass photosynthetic efficiency was measured postspill. Shoot densities and percent elongation of rhizome internodes formed after the oil spill varied but with no consistent relationship to adjacent shoreline cleanup assessment team (SCAT) oiling categories. Similarly, differences in seagrass photosynthetic efficiency were not consistent with SCAT oiling categories. While thresholds for negative impacts on seagrass in general remain to be defined, conclusive oiling indicators for degree and duration of exposure would be important considerations and need examination under controlled study.
\end{abstract}




\section{Introduction}

Seagrasses have long been exposed to oil spills yet there is little consensus on the circumstances under which impacts to their growth and distribution occur. As will be seen, there are many events where impacts have been observed, yet also many in which no discernible effects were reported. However, in the wake of the MC-252 oil spill in the Gulf of Mexico there has been renewed interest regarding the impact of oil on coastal ecosystems, including seagrasses. From claims associated with the MC-252 spill, billions of dollars of restoration funds have become available and significant effort is being expended in determining the most efficacious application of those funds. Vast resources have also been expended in determining the impacts of the spill on those coastal ecosystems ${ }^{1}$. Extensive reporting has occurred on fish, birds, oysters, crabs and salt marsh (e.g., Silliman et al. 2012, Fodrie et al. 2014) and approximately 271 acres of seagrass were considered lost due to immediate or delayed oil exposure ${ }^{2}$ (not including propeller scarring associated with spill response activities $\left.{ }^{3}\right)$ (Cosentino-Manning et al. 2015). Broad areas supporting seagrasses in the northern Gulf of Mexico had potential exposure to oil from this spill and, to an unknown degree, spill-associated dispersants.

Given the apparent absence of widespread injury to seagrasses associated with MC-252, we sought to understand the status of oil impacts on seagrasses in general. Here, we review a wide range of the readily available literature that reports on oil spill impacts to

\footnotetext{
${ }^{1}$ http://response.restoration.noaa.gov/deepwaterhorizon

${ }^{2}$ http://www.gulfspillrestoration.noaa.gov/restoration-planning/gulf-plan/

${ }^{3}$ http://www.gulfspillrestoration.noaa.gov/wp-content/uploads/2011/08/EA-for-Emergency-Seagrass-Restoration-inthe-Gulf-of-Mexico-Final-7-7-2011.pdf
} 
seagrasses. Additionally, we provide a case study of another spill (Cosco Busan, 2007) and efforts to detect spill-related impacts using both biometric and photophysiological methods. Our goal was to attempt to provide an up-to-date assessment of the vulnerability of seagrasses themselves to oil spill events.

\section{Review of oiling effects on seagrass}

As a first step in providing context to this particular event, we conducted a survey of readily available literature where specific information was given regarding the response of seagrass to oil and/or dispersants (Table 1). Many studies have examined the effects of oil on seagrasses (e.g, den Hartog and Jacobs 1980, Hatcher and Larkum 1982, Zieman et al. 1984, Thorhaug et al. 1986), yet consensus on impacts to the overall health of seagrass is lacking due to a high degree of variability in oiling scenarios and potentially response among seagrass species. Prior to the 1980s it appears that the general belief was that seagrasses were not highly susceptible to oil effects, except when physically covered with oil or when dispersants were used. More recent studies suggest that when oil is in direct contact with seagrasses it can lead to blade, if not shoot mortality (Jackson et al. 1989, Marshall 1990). Additionally, based on observations of marsh plants it appears that leaf fouling by oil produces much more immediate effects to above-ground vegetation than does fouling of the sediment surface (Hester and Mendelssohn 2000). Accumulated petro-chemicals within the sediment reduce gas exchange by killing microbes and creating elevated anaerobic soil conditions (Hester and Mendelssohn 2000). However, it is unknown whether sediment fouling by oil in seagrass systems may subject below- 
ground plant tissue to more persistent petro-chemical toxin exposure. Such conditions may be toxic to belowground tissues resulting in reduced rhizome expansion rates and below-ground biomass. Reproduction may also be affected by oiling. For example, marsh flowers that are oiled rarely produce viable seed (Baker 1971), but to our knowledge it is not known if seagrass flowers also abort seeds when oiled. 
Table 1. Comparison of oil spill and dispersant effects on seagrasses. Event names in italics are vessel names. Effect ranks: $\mathrm{N}=$ no negative effect described; $\mathrm{Y}=$ yes, negative effects described; $\mathrm{T}=$ temporary negative effects described.

\begin{tabular}{|c|c|c|c|c|c|c|c|}
\hline $\begin{array}{l}\text { Ye } \\
\text { ar }\end{array}$ & $\begin{array}{l}\text { Author } \\
\mathrm{s}\end{array}$ & $\begin{array}{l}\text { Seagrass } \\
\text { species }\end{array}$ & $\begin{array}{l}\text { Fiel } \\
\text { d or } \\
\text { Lab }\end{array}$ & Event & $\begin{array}{l}\text { Oil \&/or } \\
\text { dispersant } \\
\text { involved }\end{array}$ & Effect description & $\begin{array}{l}\text { Effect } \\
\text { rank }\end{array}$ \\
\hline $\begin{array}{l}19 \\
62\end{array}$ & $\begin{array}{l}\text { Diaz- } \\
\text { Piferrer }\end{array}$ & $\begin{array}{l}\text { Thalassia } \\
\text { testudinum }\end{array}$ & $\mathrm{F}$ & $\begin{array}{l}\text { Argea Prima, } \\
\text { Puerto Rico }\end{array}$ & Crude oil & $\begin{array}{l}\text { T. testudinum } \\
\text { "degenerated" }\end{array}$ & $\mathrm{Y}$ \\
\hline $\begin{array}{l}19 \\
70\end{array}$ & $\begin{array}{l}\text { Rutlzer } \\
\text { and } \\
\text { Sterrer }\end{array}$ & T. testudinum & $\mathrm{F}$ & $\begin{array}{l}\text { Witwater, Bahia } \\
\text { Las Minas, } \\
\text { Panama }\end{array}$ & $\begin{array}{l}\text { Diesel \& } \\
\text { Bunker C }\end{array}$ & None & $\mathrm{N}$ \\
\hline $\begin{array}{l}19 \\
73\end{array}$ & Chan & $\begin{array}{l}\text { Phyllospadix } \\
\text { spp. }\end{array}$ & $\mathrm{F}$ & $\begin{array}{l}\text { Vessel collision; } \\
\text { California }\end{array}$ & Bunker C & $\begin{array}{l}\text { "A slight die-off at the } \\
\text { outer tips of the blades } \\
\text { was recorded in February, } \\
\text { but growth of the surf } \\
\text { grass during the remaining } \\
\text { spring and into the } \\
\text { summer months appeared } \\
\text { normal." }\end{array}$ & $\mathrm{T}$ \\
\hline $\begin{array}{l}19 \\
76\end{array}$ & $\begin{array}{l}\text { Birkeland } \\
\text { et al }\end{array}$ & T. testudinum & $\mathrm{F}$ & $\begin{array}{l}\text { Witwater, Bahia } \\
\text { Las Minas, } \\
\text { Panana }\end{array}$ & $\begin{array}{l}\text { Diesel \& } \\
\text { Bunker C }\end{array}$ & None & $\mathrm{N}$ \\
\hline $\begin{array}{l}19 \\
77\end{array}$ & Chan & T. testudinum & $\mathrm{F}$ & Garbis, Florida & $\begin{array}{l}\text { Crude } \\
\text { clingage }\end{array}$ & $\begin{array}{l}\text { Seagrass injury not noted } \\
\text { (H. wrightii, S. filiforme, } \\
\text { T. testudinum) }\end{array}$ & $\mathrm{N}$ \\
\hline $\begin{array}{l}19 \\
77\end{array}$ & $\begin{array}{l}\text { Nadeau } \\
\text { and } \\
\text { Bergquist }\end{array}$ & T. testudinum & $\mathrm{F}$ & $\begin{array}{l}\text { Zoe } \\
\text { Colocotronis, } \\
\text { Puerto Rico }\end{array}$ & Crude Oil & $\begin{array}{l}\text { Some } T \text {. testudinum die- } \\
\text { off with later regrowth }\end{array}$ & $\mathrm{T}$ \\
\hline $\begin{array}{l}19 \\
80\end{array}$ & $\begin{array}{l}\text { den } \\
\text { Hartog \& } \\
\text { Jacobs }\end{array}$ & Zostera marina & $\mathrm{F}$ & $\begin{array}{l}\text { Amoco Cadiz, } \\
\text { France }\end{array}$ & $\begin{array}{l}\text { Crude \& fuel } \\
\text { oil }\end{array}$ & "Not harmed at all" & $\mathrm{N}$ \\
\hline $\begin{array}{l}19 \\
80\end{array}$ & Jacobs & Z. marina & $\mathrm{F}$ & $\begin{array}{l}\text { Amoco Cadiz, } \\
\text { France }\end{array}$ & $\begin{array}{l}\text { Crude \& fuel } \\
\text { oil }\end{array}$ & "temporary phenomenon" & $\mathrm{T}$ \\
\hline $\begin{array}{l}19 \\
82\end{array}$ & $\begin{array}{l}\text { Hatcher \& } \\
\text { Larkum }\end{array}$ & $\begin{array}{l}\text { Posidonia } \\
\text { australis }\end{array}$ & $\mathrm{L}$ & Florida & $\begin{array}{l}\text { Crude \& } \\
\text { Corexit } 8667\end{array}$ & $\begin{array}{l}\text { Plants survived and } \\
\text { continued to grow at pre- } \\
\text { treatment rates. }\end{array}$ & $\mathrm{N}$ \\
\hline $\begin{array}{l}19 \\
84\end{array}$ & $\begin{array}{l}\text { Zieman et } \\
\text { al. }\end{array}$ & $\begin{array}{l}\text { Halodule } \\
\text { wrightii, } \\
\text { Syringodium } \\
\text { filiforme, T. } \\
\text { testudinum, Z. } \\
\text { marina }\end{array}$ & $\mathrm{F} / \mathrm{L}$ & $\begin{array}{l}\text { General review; } \\
\text { papers cited } \\
\text { elsewhere in this } \\
\text { table }\end{array}$ & $\begin{array}{l}\text { Numerous, } \\
\text { citing other } \\
\text { studies }\end{array}$ & $\begin{array}{l}\text { Concluding insufficient } \\
\text { information has been } \\
\text { developed; we note that } \\
\text { most of the } \\
\text { recommendations for } \\
\text { future research described } \\
\text { in the paper has not been } \\
\text { carried out at the time of } \\
\text { this paper }\end{array}$ & $\mathrm{N}$ \\
\hline
\end{tabular}




\begin{tabular}{|c|c|c|c|c|c|c|c|}
\hline $\begin{array}{l}19 \\
84\end{array}$ & $\begin{array}{l}\text { Baca and } \\
\text { Gettner }\end{array}$ & T. testudinum & $\mathrm{L}$ & $\begin{array}{l}\text { Florida, } \\
\text { experimental } \\
\text { systems }\end{array}$ & $\begin{array}{l}\text { Prudhoe Bay } \\
\text { Crude \& } \\
\text { Corexit } 9527\end{array}$ & $\begin{array}{l}\text { Crude oil was found to be } \\
\text { more toxic than dispersed } \\
\text { oil or dispersant alone; } \\
\text { green leaves were used as } \\
\text { an indicator of effect and } \\
\text { plant structure was } \\
\text { examined for its } \\
\text { mitigative aspects }\end{array}$ & $\mathrm{Y}$ \\
\hline $\begin{array}{l}19 \\
85\end{array}$ & $\begin{array}{l}\text { Thorhaug } \\
\text { et al }\end{array}$ & $\begin{array}{l}\text { Halodule } \\
\text { wrightii, } \\
\text { Syringodium } \\
\text { filiforme, T. } \\
\text { testudinum }\end{array}$ & $\mathrm{F}$ & Jamaica & “oil" & $\begin{array}{l}\text { Experiment terminated } \\
\text { due to wave disruption - } \\
\text { effect not determined }\end{array}$ & $\mathrm{N}$ \\
\hline $\begin{array}{l}19 \\
86\end{array}$ & $\begin{array}{l}\text { Thorhaug } \\
\text { et al }\end{array}$ & $\begin{array}{l}\text { H. wrightii, } S \text {. } \\
\text { filiforme, } \\
\text { T. testudinum }\end{array}$ & $\mathrm{L}$ & Florida & $\begin{array}{l}\text { Louisiana } \\
\text { crude, } \\
\text { Murban \& } \\
\text { Corexit } 9527\end{array}$ & $\begin{array}{l}\text { H. wrightii and } S \text {. } \\
\text { filiforme: LD50 at } 75 \mathrm{ml} \\
\text { dispersed oil in } 1001 \\
\text { seawater for } 100 \mathrm{~h} . T . \\
\text { testudinum: } \mathrm{LD} 50 \text { at } 125 \\
\text { ml in } 1001 \text { seawater for } \\
100 \mathrm{~h} \text {. Dispersant had } \\
\text { significant effect on } H \text {. } \\
\text { wrightii and } S . \text { filiforme } \\
\text { but not on } T . \text { testudinum }\end{array}$ & $\mathrm{N}$ \\
\hline $\begin{array}{l}19 \\
87\end{array}$ & $\begin{array}{l}\text { Ballou et } \\
\text { al }\end{array}$ & T. testudinum & $\mathrm{F}$ & Alaska & $\begin{array}{l}\text { Dispersed } \\
\text { Prudhoe Bay } \\
\text { crude; } \\
\text { commercial } \\
\text { dispersant: } \\
\text { undefined }\end{array}$ & $\begin{array}{l}\text { "No significant effects on } \\
\text { seagrass growth rates or } \\
\text { blade areas were } \\
\text { measured" }\end{array}$ & $\mathrm{N}$ \\
\hline $\begin{array}{l}19 \\
87\end{array}$ & $\begin{array}{l}\text { Thorhaug } \\
\text { \& Marcus }\end{array}$ & $\begin{array}{l}\text { H. wrightii, S. } \\
\text { filiforme, } \\
\text { T. testudinum }\end{array}$ & $\mathrm{L}$ & Florida & $\begin{array}{l}\text { Louisiana } \\
\text { crude, } \\
\text { Murban \& } \\
\text { Corexit } 9527\end{array}$ & $\begin{array}{l}\text { At recommended } \\
\text { concentrations (below } 1 \\
\text { ml dispersant with } 10 \mathrm{ml} \\
\text { oil in } 100000 \mathrm{ml} \text { ), no } \\
\text { large mortality after } 100 \\
\text { h. At an order of } \\
\text { magnitude higher, } \\
\text { especially for longer time } \\
\text { periods S. filiforme and } \\
\text { then } H \text {. wrightii } \\
\text { succumbed }\end{array}$ & $\mathrm{Y}$ \\
\hline $\begin{array}{l}19 \\
89\end{array}$ & $\begin{array}{l}\text { Jackson et } \\
\text { al }\end{array}$ & T. testudinum & $\mathrm{F}$ & $\begin{array}{l}\text { Bahia Las } \\
\text { Minas , Panama }\end{array}$ & $\begin{array}{l}\text { Medium } \\
\text { crude; Corexit } \\
9527\end{array}$ & $\begin{array}{l}\text { Intertidal } T \text {. testudinum in } \\
\text { contact with oil observed } \\
\text { as killed; subtidal } \\
\text { survived. }\end{array}$ & $\mathrm{Y}$ \\
\hline $\begin{array}{l}19 \\
90\end{array}$ & Marshall & T. testudinum & $\mathrm{F}$ & $\begin{array}{l}\text { Bahia Las } \\
\text { Minas , Panama }\end{array}$ & $\begin{array}{l}\text { Medium } \\
\text { crude; Corexit } \\
9527\end{array}$ & $\begin{array}{l}\text { Intertidal } T \text {. testudinum in } \\
\text { contact with oil observed } \\
\text { as killed; subtidal } \\
\text { survived. }\end{array}$ & $\mathrm{Y}$ \\
\hline
\end{tabular}




\begin{tabular}{|c|c|c|c|c|c|c|c|}
\hline $\begin{array}{l}19 \\
93\end{array}$ & $\begin{array}{l}\text { Durako et } \\
\text { al }\end{array}$ & $\begin{array}{l}\text { Halophila } \\
\text { ovalis, } \\
\text { Halophila. } \\
\text { stipulacea, } \\
\text { Halodule } \\
\text { uninervis }\end{array}$ & $\mathrm{L}$ & Arabian Gulf & Kuwait crude & $\begin{array}{l}\text { No significant effects on } \\
\text { photosynthesis or } \\
\text { respiration }\end{array}$ & $\mathrm{N}$ \\
\hline $\begin{array}{l}19 \\
93\end{array}$ & $\begin{array}{l}\text { Kenworth } \\
\text { y et al }\end{array}$ & $\begin{array}{l}\text { H. ovalis, } H \text {. } \\
\text { stipulacea, } H \text {. } \\
\text { uninervis }\end{array}$ & $\mathrm{F}$ & Arabian Gulf & Kuwait crude & $\begin{array}{l}\text { Approximately } 1 \text { y post- } \\
\text { event, seagrasses did not } \\
\text { experience acute or long } \\
\text { term degradation }\end{array}$ & $\mathrm{N}$ \\
\hline $\begin{array}{l}19 \\
98\end{array}$ & Dean et al & Z. marina & $\mathrm{F}$ & $\begin{array}{l}\text { Exxon Valdez, } \\
\text { Alaska }\end{array}$ & $\begin{array}{l}\text { Prudhoe Bay } \\
\text { crude }\end{array}$ & $\begin{array}{l}\text { "Injuries to eelgrass, if } \\
\text { any, appeared to be slight } \\
\text { and did not persist for } \\
\text { more than a year after the } \\
\text { spill." }\end{array}$ & $\mathrm{T}$ \\
\hline $\begin{array}{l}19 \\
98\end{array}$ & $\begin{array}{l}\text { Ralph \& } \\
\text { Burchett }\end{array}$ & H. ovalis & $\mathrm{L}$ & Australia & $\begin{array}{l}\text { Bass Strait } \\
\text { crude oil; } \\
\text { Corexit } 9527\end{array}$ & $\begin{array}{l}\text { "The } 1 \%(\mathrm{w} / \mathrm{v}) \text { solution of } \\
\text { crude oil, dispersant and } \\
\text { crude oil+dispersant had } \\
\text { minor photosynthetic } \\
\text { impacts. Generally, } \\
\text { laboratory-cultured } H \text {. } \\
\text { ovalis was remarkably } \\
\text { tolerant of petrochemical } \\
\text { exposure." }\end{array}$ & $\mathrm{T}$ \\
\hline $\begin{array}{l}19 \\
98\end{array}$ & $\begin{array}{l}\text { Sandulli et } \\
\text { al }\end{array}$ & $\begin{array}{l}\text { Posidonia } \\
\text { oceanica }\end{array}$ & $\mathrm{F}$ & Haven, Italy & Crude oil & $\begin{array}{l}\text { No change in seagrass } \\
\text { position and density one } \\
\text { year after spill event. }\end{array}$ & $\mathrm{N}$ \\
\hline $\begin{array}{l}20 \\
03\end{array}$ & $\begin{array}{l}\text { Macinnis- } \\
\mathrm{Ng} \& \\
\text { Ralph }\end{array}$ & $\begin{array}{l}\text { Zostera } \\
\text { capricorni }\end{array}$ & $\mathrm{L}$ & Australia & $\begin{array}{l}\text { Aged } \\
\text { Champion } \\
\text { crude oil, } \\
\text { VDC }\end{array}$ & $\begin{array}{l}\text { "Despite an initial decline } \\
\text { in }(\Delta \mathrm{F} / \mathrm{Fm}), \text { in situ oil- } \\
\text { exposed samples } \\
\text { recovered by the end of } \\
\text { the experiment. } \\
\text { Chlorophyll pigment } \\
\text { analysis showed only } \\
\text { limited ongoing impact in } \\
\text { both laboratory and field } \\
\text { situations." }\end{array}$ & $\mathrm{T}$ \\
\hline $\begin{array}{l}20 \\
05\end{array}$ & $\begin{array}{l}\text { Peirano et } \\
\text { al }\end{array}$ & P. oceanica & $\mathrm{F}$ & Haven, Italy & Crude oil & $\begin{array}{l}\text { Lack of rhizome growth } \\
\text { older than the time of the } \\
\text { spill as evidence of } \\
\text { mortality }\end{array}$ & $\mathrm{Y}$ \\
\hline
\end{tabular}




\begin{tabular}{|c|c|c|c|c|c|c|c|}
\hline $\begin{array}{l}20 \\
05\end{array}$ & $\begin{array}{l}\text { Scarlett et } \\
\text { al }\end{array}$ & Z. marina & $\mathrm{L}$ & U.K. & $\begin{array}{l}\text { Superdispersa } \\
\text { nt 25, Corexit } \\
9527\end{array}$ & $\begin{array}{l}\text { Both dispersants disrupted } \\
\text { the Photosystem II (PSII) } \\
\text { apparatus, known to be a } \\
\text { primary casualty during } \\
\text { stress conditions [36], } \\
\text { within the leaves of } Z \text {. } \\
\text { marina and this was found } \\
\text { to be largely irreversible, } \\
\text { especially for Corexit } \\
9527\end{array}$ & $\mathrm{Y}$ \\
\hline $\begin{array}{l}20 \\
08\end{array}$ & Nievales & $\begin{array}{l}\text { Thalassia } \\
\text { hemprichii, } \\
\text { Enhalus } \\
\text { acoroides, Cym } \\
\text { odocea } \\
\text { rotundata, C. } \\
\text { serrulata, } \\
\text { Syringodium } \\
\text { isoetifolium, H. } \\
\text { ovalis, H. } \\
\text { uninervis and } \\
\text { Halodule } \\
\text { pinifolia }\end{array}$ & $\mathrm{F}$ & $\begin{array}{l}\text { Solar 1; } \\
\text { Phillipines }\end{array}$ & Bunker & $\begin{array}{l}\text { Decrease in seagrass } \\
\text { cover and shoot density; } \\
\text { generally lower seagrass } \\
\text { cover, shoot and blade } \\
\text { densities, and above- } \\
\text { ground biomass within a } \\
\text { year after the oil spill } \\
\text { when compared to the } \\
\text { other } 2 \text { sites; a prolonged } \\
\text { decline in shoot and blade } \\
\text { densities within a year of } \\
\text { the oil spill }\end{array}$ & $\mathrm{Y}$ \\
\hline $\begin{array}{l}20 \\
08\end{array}$ & 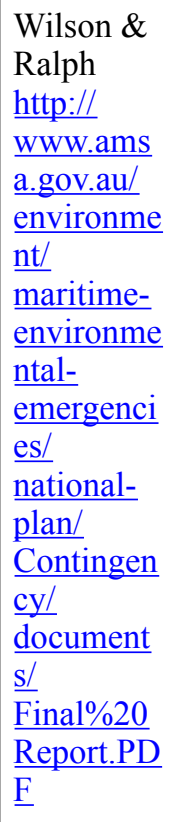 & $\begin{array}{l}\text { Z. capricorni, } \\
\text { H. ovalis, } Z \text {. } \\
\text { muelleri }\end{array}$ & $\mathrm{F} / \mathrm{L}$ & Australia & $\begin{array}{l}\text { Tapis crude, } \\
\text { IFO-380 fuel } \\
\text { oil, dispersant } \\
\text { alone (Corexit } \\
\text { 9527, Ardox } \\
6120, \\
\text { Slickgone } \\
\text { LTSW, } \\
\text { Corexit 9500) }\end{array}$ & $\begin{array}{l}\text { Non-dispersed oil led to } \\
\text { less photosynthetic stress } \\
\text { to } Z \text {. capricorni and } H \text {. } \\
\text { ovalis compared with the } \\
\text { addition of a chemical } \\
\text { dispersant. }\end{array}$ & $\mathrm{Y}$ \\
\hline $\begin{array}{l}20 \\
12\end{array}$ & $\begin{array}{l}\text { Cosco } \\
\text { Busan Oil } \\
\text { Spill } \\
\text { Trustees }\end{array}$ & Z. marina & $\mathrm{F}$ & California & $\begin{array}{l}\text { IFO-380 } \\
\text { Heavy fuel oil } \\
\text { (Bunker) }\end{array}$ & $\begin{array}{l}\text { The studies conducted } \\
\text { investigating oiling effects } \\
\text { on eelgrass beds showed } \\
\text { that, while many eelgrass } \\
\text { beds were exposed to oil, } \\
\text { there is little evidence to } \\
\text { suggest serious injuries to } \\
\text { them. }\end{array}$ & $\mathrm{N}$ \\
\hline
\end{tabular}




\begin{tabular}{|c|c|c|c|c|c|c|c|}
\hline $\begin{array}{l}20 \\
16\end{array}$ & 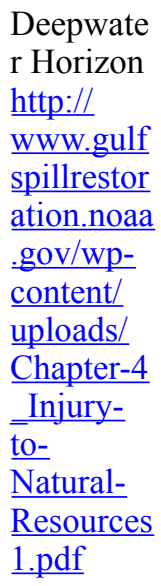 & $\begin{array}{l}\text { T. testudinum, } \\
\text { H. wrightii }\end{array}$ & $\mathrm{F}$ & Louisiana & Crude oil & $\begin{array}{l}271 \text { acres lost due to } \\
\text { immediate and delayed } \\
\text { exposure to oil. }\end{array}$ & $\mathrm{Y}$ \\
\hline
\end{tabular}


Although there have been various experiments and surveys regarding seagrass' physiological response to oiling (see review, Table 1), results vary among species regarding their to oiling impacts for reasons that are not yet understood, some of which may be more scenario-dependent than species-dependent. For example, benthic respiration rates of Posidonia australis increased with oiling, indicating stress, yet leaf turnover - a response averaging plant health over longer time periods - was not affected (Hatcher and Larkum 1982). An examination of lethal dose limits (LD L0 $_{50}$ to several Caribbean seagrass species identified plant death was less affected by oiling type and varied more among species, with Thalassia being more tolerant to oil than Syringodium and Halodule; though, the latter two species were more impacted by dispersant application (Thorhaug et al. 1986). At Bahia Las Minas, Panama, a thick covering of oil resulted in complete loss of seagrasses (Jackson et al. 1989; Marshall 1990). Eight months after the sinking of the tanker Haven, near Arenzano, Italy, dying Posidonia oceanica plants were attributed to the incident (Sandulli et al. 1998). Nine years later, no traces of oil were found but the absence of rhizomes older than eight years was consistent with massive shoot mortality associated with the time of the sinking; rhizome growth curves agreed with expectations of suppression of growth under stressed conditions (Peirano et al. 2005).

In contrast, other studies have detected non-significant impacts to seagrasses arising from oiling. Though there were strong trends in decreased shoot density and flowering shoots, no statistically valid impact to Zostera marina was determined from the Exxon Valdez 
spill (Dean et al. 1998), which was at the time the largest oil spill in U.S. history. Moreover, no significant photosynthetic impacts were detected during experimental assessments of oiling for Halophila ovalis, H. stipulacea, and H. uninervis (Durako et al. 1993), and for Z. capricorni (Wilson and Ralph 2010; Macinnis-Ng and Ralph (2003) also found little impact in Z. capricorni exposed to oil in the field, though lab exposures caused significant effects). Oil dispersants were found to have detrimental effects to seagrass photosynthesis (Ralph and Burchett 1998; Scarlett et al. 2005; Macinnis-Ng and Ralph 2003) and at elevated concentrations were lethal to some seagrass species (Thorhaug and Marcus 1987; Scarlett et al. 2005). Use of oil dispersants may negatively affect seagrass more than oiling alone (Hatcher and Larkum 1982). Clean-up efforts may also directly affect seagrasses by compacting or disturbing sediments; prolonged periods of increased turbidity from sediment resuspension associated with clean-ups also may also reduce light availability to seagrass plants which would yield a drop in standing stock (sensu Short et al. 1995).

Here, we compared seagrass conditions both pre- and post-spill for the Cosco Buscan event at several sites across a wide spatial extent of San Francisco Bay representing varying levels of potential oil exposure. Given the lack of consistent responses of seagrasses to oiling events and the variety of assessment protocols for determining seagrass impacts, we conducted an assessment of eelgrass (Zostera marina) across a gradient of oil spill exposure associated with the Cosco Busan oil spill. As there review above notes, there is no clear pattern of response to indicate a superior metric. For this 
study, we chose metrics that would detect longer-term effects that would have influence on the population ecology of the plant communities (including comparisons with pre-spill surveys in these areas) as well as more immediate effects associated with the plant's physiology. We measured shoot densities (a common seagrass measurement and comparative with previous studies), reproductive status, rhizome growth curves (indicating potential for space occupation) and photosynthetic capacity (i.e., comparatively immediate effects rather than integrating effects over time) of eelgrass along a gradient of oiled and unoiled sites. The information collected was part of the Natural Resource Damage Assessment (NRDA) framework established by the Oil Pollution Act of 1990 (OPA) and was utilized to help determine the degree of injury, if any, to seagrass beds in the Bay and guide the extent of any needed compensatory restoration project.

Our goals here were to both provide a context for the Cosco Busan event, but also reach some conclusion as to under what circumstances injury to seagrass might occur from an oil spill event. Having some perspective on when seagrass may actually be injured would be useful in guiding future responses where seagrasses exist within the threatened area.

\section{Summary of Cosco Busan Spill}

On November 7, 2007, the container ship Cosco Busan struck the Oakland-Bay Bridge in San Francisco Bay spilling an estimated 53,569 gallons of IFO380 bunker fuel oil (approximately 1,700 barrels; in contrast the Deepwater Horizon event released an 
estimated 4 million barrels). The spill occurred during a neap tide cycle near the height of the incoming tide. Strong winds and the subsequent outgoing tide transported surface oil out of the mouth of the Bay and northward along the coastline yet some of the oil was retained within the Bay. Shoreline cleanup assessment teams (SCAT) and clean-up responses by private, government, and public organizations provided near real-time documentation of the oiling extent and enhanced control over the affected areas potentially reducing the overall distribution of the oil (Holton and Dunagan 2010). Although surveys could not be conducted directly in the eelgrass beds due to tidal conditions, it was estimated that based on SCAT surveys of the adjacent shorelines that 939 acres of eelgrass was exposed to oil in varying degrees (Cosco Buscan Trustees 2012).

\section{Methods}

\subsection{Site characteristics}

Potentially impacted and control site designation were first determined from detailed aerial and boat reconnaissance by SCAT data collected during the event that delineated the degree of shoreline oiling (Holton and Dunagan 2010). Site selection was then conducted across this observed gradient of oiled shoreline sites (impacted) versus unoiled (control) areas utilizing previously established, ongoing Z. marina study sites that allowed before and after comparisons of potential effects across a wide range of seagrass landscape patterns, elevations, wave exposure, and sediment types of eelgrass beds around the Bay. Sites surveyed from November 25-27, 2007 are identified in Fig. 1. The 
previously established study sites existed from an effort to evaluate the Bay's seagrass bed life history and recovery potential (author's unpublished data ${ }^{4}$ ).

SCAT teams conducted shoreline and near-shore subtidal oiling assessments for the purpose of response and clean-up. The degree of oiling of eelgrass beds was calculated separately under the NRDA for intertidal ( $0-4 \mathrm{ft}$.) and subtidal (greater than $4 \mathrm{ft}$.) meadows relative to the apparent high tide line at a site. The intertidal beds were assigned a degree of oiling equivalent to the most prominent maximum oiling observed, as defined by SCAT data, on the closest adjacent shoreline to the intertidal bed. Subtidal beds were then automatically assigned an oiling one degree lighter than the oiling assigned to the adjacent intertidal beds. However, our sampling utilized portions of the seagrass beds that were exposed at low tides which was also where previous (pre-spill) sampling had occurred. We define exposure as whether the seagrass blades were either emersed or largely laying across the water surface at low tide. This suggests that our sample locations had the potential for interaction with oil if the tide was low when oil was present.

NRDA teams recorded qualitative information from each site describing the general characteristics of the seagrass bed and nearby habitats as well as the type, condition, and extent of observed oil (Table 2). Within the seagrass meadow at each site the visible presence and description of oil on the sediment or plant surface (SO) was recorded. Arbitrarily distributed pits were dug along a survey transect (see section 2.2, below) to

\footnotetext{
${ }^{4}$ Fonseca, M.S., S. Wyllie-Echeverria, C. Addison, and T. Wyllie-Echeverria. 2003. NOAA Joint Pilot Project on Eelgrass (Zostera marina L.) Recovery in San Francisco Bay. Internal report
} 
determine if subsurface oil (SSO) was released (sensu Taylor and Reimer 2008). Any oil or tar balls found on the plant surface were recorded and sampled. Any non-visible oiling, such as polycyclic aromatic hydrocarbon absorption, was not detectable with the methods used.

\subsection{Demographic characteristics}

Seagrass leaf production coincides with the belowground production of rhizome nodes; thus if plants are experiencing stress, such as that due to oiling, we expected that a response could would be manifested as a morphologically detectable reduction of growth to above and belowground structures of the plant (Tomlinson 1974; sensu Duarte et al. 1994). Observations of seagrass meadow distribution and visual presence of oil on plants as well as quantifying aboveground (shoot density) and belowground plant metrics (rhizome expansion) were recorded to document the condition of each surveyed site.

Following methods previously used at many of the sites (Fonseca et al. 2003) a 100m transect tape was placed parallel to shore within eelgrass beds at the highest elevation of eelgrass distribution, a location typically emergent at low tide and thereby overlapping the area most likely affected by oiling. Ten quadrats $\left(0.25 \mathrm{~m}^{2}\right)$ were haphazardly placed along the transect within which eelgrass shoots were counted and plants were inspected for evidence of surface oil (as per section 2.1, above). During the time of our survey, no flowering shoots were encountered within the quadrats, thus all data reported are densities of vegetative shoots. Thirty haphazardly selected plants, with above- and 
below-ground structures intact, were collected for below-ground analysis and closer examination of above-ground surfaces for oil presence at all sites except $\mathrm{HC}$ and $\mathrm{CB}$, due to the very patchy nature of the bed and low shoot densities. Where sites overlapped with previous surveys ( 8 out of 11 total), shoot densities were then compared with those previously measured (by site) using natural log transformed shoot density values (Proc GLM, Student Newman Kuels; SAS $®)$.

Potential morphological manifestations of oiling were also evaluated by analyzing recent rhizome node production. Previous studies conducted in San Francisco Bay indicate node formation occurs approximately every 15 days (Fonseca et al. 2003; Phillips 1984). From the shoots retained from the random quadrats we measured the four youngest complete internode lengths, which would document growth for approximately 60 days, encompassing the time period immediately before and after the Cosco Busan spill. The relative size of the rhizome internode lengths was used as surrogates for comparative measures of both rhizome extension itself and implicitly, leaf emergence rates because node formation is synchronized with leaf emergence in Z. marina. Internode measurements were collected between root nodes using a digital caliper, measuring to the nearest $0.01 \mathrm{~mm}$. Internodes were enumerated as: internode $1=$ most recent complete internode (post spill) to internode $4=$ oldest (approximately 2 months old). Due to natural variability in plant size, in which larger, more robust rhizomes produce longer internode lengths (Duarte 1991), fractional growth rates were used in this analysis to standardize growth among plants. Fractional growth rates were calculated as a given 
internode length divided by the sum of that plant's total internode lengths (four most recently fully formed internodes). Using quadrat means as replicates within a site, we performed a one-way analysis of variance (Proc GLM, SAS ver. 9.2) of the percent elongation of each of the two most recently formed internodes, among sites grouped by oiling category. Data normalized prior to analysis via $\log 2$ transformation.

\subsection{Seagrass photosynthesis}

To test for potential photosynthetic impacts of oiling, three intact $Z$. marina plants were collected from each of the 10 quadrats at the initial sites (PSP, PO, AI, KC; CB and HC were not sampled due to logistical constraints), held in seawater-filled (ambient) plastic bags and returned in coolers to the Romberg Tiburon Center for Environmental Studies (at San Francisco State University) for fluorometric analysis. Due to time constraints only one plant per quadrat was assessed at the remaining sites (PC, EV, BF, KB, CC). Plants were held in seawater at ambient temperature in covered outdoor seawater tanks. The flow-through seawater system at the Romberg Tiburon Center was not functioning due to the spill, so plants were kept in open containers filled with seawater, with water changes completed as necessary. All measurements were made within $24 \mathrm{~h}$ of plant collection.

All plants were standardized to a light exposure of $500 \mu \mathrm{mol}$ quanta $\mathrm{m}^{-2} \mathrm{~s}^{-1}$ at ambient temperature for at least $20 \mathrm{~min}$ prior to measurements. This is higher than previously 
reported saturation intensities for Z. marina in San Francisco Bay (e.g. Zimmerman et al. 1991), but all sites surveyed in this study are intertidal beds and $500 \mu \mathrm{mol}$ quanta $\mathrm{m}^{-2} \mathrm{~s}^{-1}$ is well below what the plants would experience when emergent at low tide. Photosynthetic characteristics of Z. marina were then assayed using rapid light curve (RLC) techniques adapted from Ralph and Gademann (2005). The optical probe of a DIVING-PAM (Walz $\mathrm{GmbH}$ ) fluorometer was fixed orthogonal to and $4 \mathrm{~mm}$ from the leaf blade. As photosynthetic characteristics vary with leaf rank (Durako and Kunzelman 2002, SasilOrbita and Mukai 2006), fluorescence measurements were made on the second youngest leaf $2-5 \mathrm{~cm}$ from where it emerged from the sheath (Ralph and Gademann 2005). Plants were subjected to 10 s of quasi-darkness, followed by RLCs using stepped actinic illumination 10s in duration (Ralph and Gademann 2005). Light levels ranged from 56-862 $\mu$ mol quanta $\mathrm{m}^{-2} \mathrm{~s}^{-1}$, as measured with the PAM's light meter calibrated against a Licor LI-192 SA quantum sensor.

Effective quantum yield $\left(\Delta \mathrm{F} / \mathrm{F}_{\mathrm{m}}{ }^{\prime}=\mathrm{F}-\mathrm{F}_{\mathrm{m}}{ }^{\prime} / \mathrm{F}_{\mathrm{m}}{ }^{\prime}\right.$, where $\mathrm{F}$ is initial fluorescence and $\mathrm{F}_{\mathrm{m}}{ }^{\prime}$ is maximum fluorescence; Walz 1998) was calculated from the initial step in the RLC. However, we also quantitatively compared the RLCs by treating the data as a photosynthetic-irradiance (P-E) curve. Leaf absorption factor (AF; calculated after the methods of Beer et al. 2001) was $0.66 \pm 0.01$ (average \pm SE). However, given the disconnect between molar oxygen and electron transport in Z. marina and potentially inadequate determinations of leaf absorption factor for that species (Beer et al. 1998) and that we had no means to ground-truth AF via other photosynthetic measurements, we 
instead report relative electron transport rates were calculated as $\mathrm{rETR}=$ photosynthetic

yield x PAR x 0.5 x 0.84 (Beer et al. 2001). P-E curve characteristics ( $\alpha=$ initial slope of the curve and maximum relative Electron Transport Rate) were estimated using a Marquardt-Levenberg regression algorithm (Ralph and Gademann 2005), and compensation irradiance $\mathrm{E}_{\mathrm{k}}$ was calculated as $\mathrm{rETRmax} / \alpha$. Effective quantum yield $(\Delta \mathrm{F} /$ $\mathrm{F}_{\mathrm{m}}$ ') and light curve slope $(\alpha)$ data did not meet parametric assumptions after arcsin transformation, and were analyzed with a Kruskal-Wallis non-parametric Analysis of Variance. rETRmax met parametric assumptions, as did log-transformed $E_{k}$ data. These data were analyzed via ANOVA, with Tukey unequal n post-hoc comparisons. All PAM data were analyzed in STATISTICA (StatSoft Inc. 2003).

\section{Results}

\subsection{Site characteristics}

Five of the 10 surveyed sites experienced some degree of oiling (Table 2). SCAT surveys confirmed the control sites, PO and PSP, did not receive visually detectable levels of oiling due to the Cosco Busan spill. At the time of the SCAT surveys, visual estimates of surface and subsurface oil were not made at five sites, due to submersion of eelgrass plants (identified as nd on Table 2). However, a surface sheen was observed at HC within the area of seagrass distribution and the remaining four sites were otherwise within the geographic area where oil had been otherwise observed. 
Heavy oiling was observed at $\mathrm{HC}, \mathrm{KC}$, and $\mathrm{KB}$ but outside the area of seagrass distribution yet within the embayment of the study site. HC contained a band of oil extending along the adjacent rip rap approximately $100 \mathrm{~m}$ long by $15 \mathrm{~cm}$ wide. Here, the band of oil was approximately $2 \mathrm{~m}$ above the depth at which seagrass occurred. Oiled seagrass wrack was found at the high tide line but intact plants appeared free of oil. Similarly, a coat of oil extended along the rocky edge of the KC shoreline, approximately $2 \mathrm{~m}$ above seagrass distribution, encompassing an area of more than $100 \mathrm{~m}$ long and $20 \mathrm{~cm}$ wide. At KB, the oil band also $20 \mathrm{~cm}$ wide, extended nearly $200 \mathrm{~m}$ along shore, covering $51-90 \%$ of the affected area. The upper edge of the KB seagrass meadow was approximately $1 \mathrm{~m}$ below the observed oil band. Here, a heavy oil film on the beach cobble and bedrock as well as three small tar balls on a boulder above (approximately 1 m) the distribution of eelgrass was found. At all other sites, no evidence of tar or oil was observed within or adjacent to the eelgrass meadow surveyed. During our surveys for this post-event study, we did not observe oil or oil sheen at any of the sampling sites, suggesting that the exposure period for seagrass to oil had largely ended. As there is no way to quantify the duration or degree of exposure for the seagrass beds we sampled (which are largely intertidal or barely subtidal), the SCAT categories remain the best available proxy.

Some cleanup activities were conducted at surveyed sites, $\mathrm{HC}, \mathrm{KC}$, and $\mathrm{KB}$ prior to the eelgrass sampling. A film of heavy oiling was reported on the rip rap, delineating the tide level at the time of oil impact at HC. Attempts at removing the oil from rip rap were 
made by cleanup teams using cold water spray treatment; the cleaning attempt was not successful. At KC, clean up attempts were evident; rocks were scrubbed and larger, heavily oiled rocks were left in piles for removal later. In addition to the rock piles, we observed a coat of oil that remained on bedrock and smaller gravel and cobble. However, we did not observe oil on seagrass at any time.

\subsection{Demographic characteristics}

Substantial differences of shoot densities were found among sites both pre- and post-spill (Fig. 2) with mean site shoot densities ranging from approximately $10-78$ vegetative shoots $\mathrm{m}^{-2}$. Where data existed on sites both pre- and post-spill, (8 out of 11 sites) three sites had lower shoot densities post-spill (Table 3), while there were no other significant differences among sites. However, pre-spill shoot densities were averaged from surveys conducted in April and July versus those conducted post-spill which were during late November, a seasonal difference that could contribute to shoot density differences. Additionally, the variability in shoot density did not appear to form any discernible pattern with potential oiling, as demonstrated by the lack of pattern in differences of shoot density by SCAT oiling category (Fig. 2); e.g., shoot densities from Keller Beach (moderate SCAT oiling) were not significantly different from those with light to very light oiling (Fig. 2). Highest shoot densities were found at EV, HC and PO. These sites were widely separated across the Bay (Fig. 1) and SCAT data suggested a range of potential oiling exposure (Table 2). Similarly, the significant differences detected in shoot densities at sites pre- versus post-spill were also spread across SCAT categories, 
indicating no obvious association of potential oiling intensity with changes in shoot density. The lowest shoot densities were recorded at CB; a very lightly oiled site that had a patchy distribution of seagrass cover and overall low shoot densities previously.

If seagrass plants were affected by oiling, one might also expect rhizome growth to decline following the spill as a function of oiling intensity. A variety of responses was observed, from increasing, decreasing, to no change in rhizome extension over the most recent two month period (Fig. 3; Table 4). An increasing rhizome growth was detected at $\mathrm{PO}$ and $\mathrm{KB}$, signaling an increase in the rate of lateral expansion (Fig. 3) despite being at opposite ends of the SCAT data from the spill. Rhizome growth generally declined during the study period at sites with no to light oiling (PSP, BF, PC, AI; Fig. 3) yet the decline often began prior to the oil spill. There was no significant within-site change in rhizome expansion over the last two months at three oiled sites (EV, KC, CC; Fig. 3;), while unoiled PO and PSP showed opposite trends in growth.

\subsection{Seagrass photosynthesis}

Average effective quantum yields at the nine sites ranged from 0.745 to 0.692 (Fig. 4). Effective quantum yield varied significantly with oiling category (Kruskal-Wallis $\mathrm{H}=$ $30.42, \mathrm{df}=4, \mathrm{p}<0.001)$, but not in order of SCAT category. For example, lightly oiled sites had significantly higher $\Delta \mathrm{F} / \mathrm{F}_{\mathrm{m}}$ ' than both moderately oiled sites and sites with no oil (both $\mathrm{p}<0.001$ ). There was also no difference in $\Delta \mathrm{F} / \mathrm{F}_{\mathrm{m}}$ ' between sites at the extreme ends of the SCAT spectrum. There were also significant differences in $\triangle \mathrm{F} / \mathrm{F}_{\mathrm{m}}$ ' between 
sites (Fig. 4; Kruskal-Wallis $\mathrm{H}=40.63$, $\mathrm{df}=8, \mathrm{p}<0.001$ ), but again without clear relationships to oiling categories. Lightly-oiled AI had a higher yield that moderately oiled CC $(p=0.001)$ and $\mathrm{KB}(\mathrm{p}=0.015)$, but not moderately oiled EV $(\mathrm{p}=1.0)$.

The rapid light curves for all sites showed a typical photosynthesis-irradiance relationship, with little evidence of photoinhibition (data not shown). The P-E curve characteristics are summarized in Table 5. There were no significant differences in the initial slope of the curve $\alpha$ among sites (Kruskal-Wallis $\mathrm{H}=9.00, \mathrm{df}=8, \mathrm{p}=0.34$ ).

There were site-specific differences in the other P-E curve parameters (Table 5; rETRmax $\left.\mathrm{F}_{8,160}=18.96, \mathrm{p}<0.001 ; \mathrm{E}_{\mathrm{k}} \mathrm{F}_{8,160}=12.4, \mathrm{p}<0.001\right)$, but there is no coherent pattern between statistically different photosynthetic parameters and the SCAT oiling categories. The unoiled PSP site had a higher rETRmax (all $\mathrm{p}<0.01$ ) than any oiled site, and a higher $E_{k}(p<0.05)$ than any oiled site except KB. PO was also unoiled and had the same rETRmax $(p=0.28)$ and $E_{k}(p=0.85)$ as PSP. However, there were no significant differences between PO and very lightly oiled BF or moderately oiled $\mathrm{KB}$ and $\mathrm{CC}$. Heavily oiled KC had a lower rETRmax $(p=0.04)$ and $E_{k}(p=0.023)$ than lightly oiled AI, but there were no differences between $\mathrm{KC}$ and any of the very lightly oiled (BF, PC) or moderately oiled (CC, EV, KB) sites.

\section{Discussion}

Through our review, we found at least heuristic evidence that the inconsistent effect of oil spills on seagrass beds to be a results of the many factors that combine to advance or 
conversely, mitigate the interaction of oil (and dispersants) with the seagrass ecosystem. Here, as in many oil spill events, the proximity of sites to the point of oil release, the kind of oil, the tidal stage, range and circulation patterns and the location of the seagrass in the tidal frame all likely influenced the degree and duration to which seagrass was exposed to oil. These same factors also do not allow us to determine whether the use of the shoreline SCAT data formed a useful surrogate for the exposure of seagrass to oil. Similarly, the trustees' environmental assessment and restoration plan for the Cosco Busan spill (Cosco Busan Oil Spill Trustees 2012) documented highly variable impacts to birds, fish, shoreline habitats, and human uses. Impacts were highest to organisms at or near the water surface. Rocky intertidal habitats shifted in community structure; red Porphyra algae replaced brown Fucus, while barnacles increased after the spill (Raimondi et al. 2009). Over 6000 seabirds were oiled as a result of the spill (Cosco Busan Oil Spill Trustees 2012), and oil exposure was a significant source of mortality to Pacific herring larvae spawned within 3 months of the event (Incardona et al. 2012).

Of $\sim 940$ acres of eelgrass beds exposed to oil on the spill, only 30 acres were moderately or heavily oiled (though eelgrass beds at Keil Cove [site $\mathrm{KC}$ ] were also impacted by vessel groundings related to cleanup activities). Analyses of invertebrate species diversity in eelgrass beds were inconclusive relative to degree of oiling (Cosco Busan Oil Spill Trustees 2012). California's Office of Environmental Health Hazard Assessment concluded that there was no increased risk from eating red rock crabs or fish from the spill area due to oil contamination (Brodberg et al. 2007). Similarly, Zabin et al. (2009) found no difference in oyster growth or mortality between oiled and unoiled sites, though 
total cover of benthic organisms decreased at oiled sites. However, their impacted sites were only lightly oiled (they sampled at Angel Island, quite close by the AI seagrass site in this study). Importantly, sampling in seagrass beds and of seagrasses themselves was limited as in many past events.

Here, we measured Z. marina demography and photosynthetic efficiency with the assumption that oiling impacts from the Cosco Busan spill would present themselves in an orderly (if not linear) manner with oiling intensity. These tests were conducted within 3 weeks of the accident which was as fast as resources could be mustered to reach the site. If a strong impact to $Z$. marina had occurred, the plants contained rhizome internodes formed during the accident and still would have been carrying most of the leaves present during that time. In contrast, the fluorometric response is more of a shortterm indicator, and one that has been previously used to assess oil impacts to seagrasses (Ralph and Burchett 1998, Macinnis-Ng and Ralph 2003).

No compelling relationship was found between potential oiling from the Cosco Busan spill and observed variation in Z. marina demographics. Shoot densities were generally equivalent to those seen from previous surveys conducted in 2004-5 that overlapped 8 of the 11 sites visited. Those previous surveys were conducted at the same depth zone and used the same methods (the previous survey methods defined those used in the postsurvey) but were conducted in the spring and summer versus those conducted post-spill in late November. Even though all three sites with significantly different pre- versus 
post-spill shoot densities had lower densities post-spill, those differences may simply be seasonal variability with slightly lower densities occurring later in the year. Importantly, those differences were found at three sites spanning virtually the entire range of oiling intensity (Fig. 2), which does not suggest a consistent effect of oiling on shoot density. Oiling from this event apparently did not accumulate enough material in the Z. marina habitats to occlude light to the point where a persistent depression in productivity could be found as seen in other studies. It appeared that conventionally detectable impacts to $Z$. marina from oiling, if they exist, may require a higher level of exposure and duration than observed in this event.

We must note that one site, $\mathrm{CB}$, was unique among the sites surveyed. Shoot densities recorded here were comparatively low, but representative of the site's historic average densities which have ranged from approximately 2.4 to 10.9 shoots $\mathrm{m}^{-2}$ (author's unpublished data; 2004-2005; Fig. 2). There was visible evidence of waterfowl grazing on shoots; additionally this site (CB) was patchily re-established by seedlings in the spring (author's pers. obs.) with a great deal of shoot annuality which in part accounts for the wide range of areal shoot densities. Despite the apparent effect of grazing, the shoot densities documented here were actually similar to peak biomass for the site and thus cannot be attributed to the Cosco Busan spill.

Differences in PAM data among sites in this study were also unrelated to SCAT oiling categories. Effective quantum yield values were fairly high $(\sim 0.7)$ overall, and seagrasses 
collected from heavily oiled Keil Cove (KC) were not statistically different in $\Delta \mathrm{F} / \mathrm{F}_{\mathrm{m}}$ ' than seagrasses from unoiled sites. Previous PAM studies have documented oil impacts in laboratory exposures. Cultures of Halophila ovalis exposed to a 1\% (weight:volume) Bass strait crude oil and/or dispersant mixture showed slight but significant reductions in quantum yield within an hour, with no evidence of recovery of quantum yield or photochemical efficiency $\left(\mathrm{F}_{\mathrm{v}} / \mathrm{F}_{\mathrm{m}}\right)$ for $96 \mathrm{hr}$ (Ralph and Burchett 1998).

Similarly, $0.25 \%$ crude oil and dispersant treatments reduced effective $\left(\Delta \mathrm{F} / \mathrm{F}_{\mathrm{m}}{ }^{\prime}\right)$ and maximum $\left(\mathrm{F}_{\mathrm{v}} / \mathrm{F}_{\mathrm{m}}\right)$ quantum yield in Zostera capricorni; field samples recovered within 4 days though laboratory cultures did not (Macinnis-Ng and Ralph 2003). Durako et al. (1993) exposed Halophila ovalis, H. stipulacea, and Halodule uninervis to Kuwait crude oil for 12-18 hr, and found no significant differences in $\mathrm{P}_{\max }, \alpha$, or $\mathrm{E}_{\mathrm{k}}$ with oil exposure (they used oxygen-based photosynthesis-irradiance curves, which are analogous to PAM rapid light curves). Our measurements in this study were longer-term (several weeks rather than several days), but we saw similar results here, in that differences in rETRm, $\alpha$, and $\mathrm{E}_{\mathrm{k}}$ were not consistent with SCAT oiling categories.

Overall we found no clear evidence that oiling from the Cosco Busan spill event contributed to the observed variation in Z. marina physiology. There are any number of factors that might contribute to this result. Though it is common practice to estimate subtidal oiling by reducing exposure one level relative to beach oiling categories, those SCAT data may not be a good representation of oil exposure to the seagrass beds we surveyed here because we cannot be sure that oil was present when seagrass was exposed 
at low tides. Exposure could differ across the geographic extent of an individual bed, or it could be possible that in some exposed areas, seagrass could buffer oil from reaching the beach. Pre- and post-spill data are helpful for comparison, but field data also necessarily have inherent site variability due to factors unrelated to the degree of potential oil exposure.

In addition to amount of potential exposure, the interaction mechanism could differ according to bed elevation; intertidal seagrasses can be affected by physical contact with oil, while subtidal seagrasses are more likely exposed to dispersed oil droplets (Ralph and Burchett 1998). Ultimately, it would be useful to have more direct estimates of oiling for subtidal habitats. While the shoot demographics would have integrated exposure between the oil spill and our sampling 3 weeks later, the photophysiology responds more dynamically. The primary phytotoxic effect of oil is the absorption of the water-soluble fraction. However, exposure to oil in the field may be associated with reduced physical contact time, high light levels that would have broken down oil, or biodegradation of the oil by microbial activity; experimental exposure to crude oil and dispersant treatments depressed photosynthetic responses in seagrasses, but field samples recovered within $4 \mathrm{~d}$ though laboratory cultures did not (Macinnis-Ng and Ralph 2003). It's therefore possible that the Z. marina could have recovered photosynthetic capacity within the 3 weeks between any exposure and our sampling. 
Through our review, it appeared little had changed regarding our general understanding of the effect of oil (and dispersants) on seagrass since the first general review by Zieman et al. (1984). Here, we add to the comparatively sparse (to the Atlantic basin) information on U.S. west coast seagrasses using both integrative ecological and shortterm physiological metrics. Differences were apparently not related to the proximity of oiling, although strong causative factors were likely hampered by reliance on shoreline SCAT data that may only loosely represent exposure of submerged seagrass to the oil. Understanding the duration of direct exposure of plants to oil is missing from almost all studies, depriving us of a critical normative factor for better understanding seagrass response to oil.

However, the lack of strong effects is consistent with the body of evidence which suggests that unless physically coated with oil or deprived of light by oil layers, seagrasses themselves are little damaged by proximity to oil, which is consistent with the apparent scenario in this study. Controlled studies of oil exposure and testing of seagrass physiological responses with modern methods are recommended to quantitatively define exposure limits for each seagrass species. However, each spill event is unique with respect to potential degree and duration of oiling. An event similar to the Cosco Busan, under differing timing and location in the Bay, or a larger, more lasting event could likely result in greater impacts than were observed in this study.

\section{Acknowledgements}


Support for this work was provided through the Cosco Busan Trustee Council. We appreciate the assistance from Kathy Boyer and her students at San Francisco State University's Romberg Tiburon center for vessels and facilities support. Christine Addison provided field sampling support and contributed to early versions of the manuscript, and Andrew Mason assisted with graphics. The manuscript was substantively improved by comments from Matthew Zafonte (California Department of

Fish and Wildlife, Office of Spill Prevention and Response) and Dave Whitall (NOAA). The US Geological Survey Coastal and Marine Geology program graciously loaned the PAM fluorometer for this work.

\section{References}

Baca, B.J., C.D. Getter. 1984. The toxicity of oil and chemically dispersed oil to the seagrass Thalassia testudinum. In Oil Spill Chemical Dispersants: Research, Experience, and Recommendations, STEP 840. Allen, T.E. (Ed.) American Society for Testing and Materials, Philadelphia. 314-323/

Baker, J. 1971. Seasonal effects of oil pollution on salt marsh vegetation. Oikos 22:106-110.

Ballou, T.G., Dodge, R.E., Hess, S.C., Knap, A.H., Sleeter, T.D. 1987. Effects of a dispersed and undispersed crude oil on mangroves, seagrasses, and corals. American Petroleum Institute, publication number 4460. American Petroleum Institute, Washington, D.C. 
Beer, S., Vilenkin, B., Weil, A., Veste, M., Susel, L, Eshel, A. 1998. Measuring photosynthetic rates in seagrasses by pulse amplitude modulated (PAM) fluorometry. Mar. Ecol. Prog. Ser. 174, 293-300.

Beer S., Bjork, M., Gademann, R., Ralph, P. 2001. Measurements of photosynthetic rates in seagrasses. In: Short, F.T., Coles, R.G. (eds). Global Seagrass Research Methods. Elsevier Science B.V., Amsterdam. p.183-198.

Birkeland, C., Reimer, A.A., Young, J.R. 1976. Survey of marine communities in Panama and experiments with oil. U.S. Environmental Protection Agency, $600 / 3-76-028$

Brodberg R., Klasing, S., Gassel, M., Alexeeff, G., Sanborn, J., Roberts, S., Blaisdell, R., Kim, J., Dodge, D., DuTeaux, S. 2007. Report on the safety of consuming fish and shellfish from areas impacted by the M/V Cosco Busan oil spill in San Francisco Bay, California. http://oehha.ca.gov/fish/pdf/SF\%20BayFishShell112907.pdf. Last accessed February 23, 2016.

Chan, G.L. 1973. A study of the effects of the San Francisco oil spill on marine organisms. In: Proceedings of the Joint Conference on Prevention and Control of Oil Spills: March 1983, Vol. 1973, 1, 741-781. American Petroleum Institute, Washington, D.C.

Chan, E.I. 1977. Oil pollution and tropical littoral communities: biological effects of the 1975 Florida Keys oil spill. In: International Oil Spill Conference Proceedings: March 1977, Vol. 1977, 1,539-542. American Petroleum Institute, Washington, D.C. 
Cosentino-Manning, N., Kenworthy, J., Handley, L., Wild, M., Rouhani, S., Spell, R. 2015. Submerged Aquatic Vegetation Exposure to Deepwater Horizon Spill. (NS_TR. 36). Deepwater Horizon Submerged Aquatic Vegetation NRDA Technical Working Group Report.

Cosco Busan Oil Spill Trustees. 2012. Cosco Busan Oil Spill Final Damage Assessment and Restoration Plan/Environmental Assessment. Prepared by California Department of Fish and Game, California State Lands Commission, National Oceanic and Atmospheric dministration, United States Fish and Wildlife Service, National Park Service, Bureau of Land Management. https://nrm.dfg.ca.gov/FileHandler.ashx? DocumentID=42442. Last accessed February 23, 2016.

den Hartog, C., Jacobs, R. 1980. Effects of the "Amoco Cadiz" oil spill on an eelgrass community at Roscoff (France) with special reference to the mobile benthic fauna. Helgoland Mar. Res. 33, 182-191.

Dean, T.A., Stekoll, M.S., Jewett, S.C., Smith, R.O., Hose, J.E. 1998. Eelgrass (Zostera marina L.) in Prince William Sound, Alaska: Effects of the Exxon Valdez oil spill. Mar. Pollut. Bull. 36, 201-210.

Deepwater Horizon Natural Resource Damage Assessment Trustees. (2016). Deepwater Horizon oil spill: Final Programmatic Damage Assessment and Restoration Plan and Final Programmatic Environmental Impact Statement. Retrieved from http:// www.gulfspillrestoration.noaa.gov/restoration-planning/gulf-plan

Diaz-Piferrer M.1962. Effects of an oil spill on the shore of Guanica, Puerto Rico. DeepSea Res. 2, 855-856. 
Duarte, C.M. 1991. Allometric scaling of seagrass form and productivity. Mar. Ecol. Prog. Ser. 77, 289-300.

Duarte, C.M., Marba, N., Agawin, N., Cebrian, J., Enriquez, S., Fortes, M.D., Gallegos, M.E., Merino, M., Olesen, B., Sand-Jensen, K., Uri, J., Vermaat, J. 1994. Reconstruction of seagrass dynamics: age determinations and associated tools for the seagrass ecologist. Mar. Ecol. Prog. Ser. 107, 195-209.

Durako, M.J., Kenworthy, W.J., Fatemy, S.M.R., Valavi, H., Thayer, G.W. 1993. Assessment of the toxicity of Kuwait crude oil on the photosynthesis and respiration of seagrasses of the northern Gulf. Mar. Pollut. Bull. 27, 223-227.

Durako M.J., Kunzelman, J.I. 2002. Photosynthetic characteristics of Thalassia testudinum measured in situ by pulse-amplitude modulated (PAM) fluorometry: methodological and scale-based considerations. Aquat. Bot. 73, 173-185.

Fodrie, F.J., Able, K.W., Galvez, F., Heck Jr., K.L.,Jensen, O.P., López-Duarte, P.C., Martin, C.W., Turner, R.E., Whitehead, A. 2014. Integrating organismal and population responses of estuarine fishes in Macondo spill research. BioScience 64, $778-788$

Fonseca, M.S., Wyllie-Echeverria, S.,Addison, C., Wyllie-Echeverria, T. 2003. NOAA Joint Pilot Project on Eelgrass (Zostera marina L.) Recovery in San Francisco Bay. Internal report.

Hatcher, A.I., Larkum, A.W.D. 1982. The effects of short term exposure to Bass Strait crude oil and corexit 8667 on benthic community metabolism in Posidonia australis Hook.f. dominated microcosms. Aquat. Bot. 12, 219-227. 
Hester, M.W., Mendelssohn, I.A. 2000. Long-term recovery of a Louisiana brackish marsh plant community from oil-spill impact: vegetation response and mitigating effects of marsh surface elevation. Mar. Env. Res. 49, 233-254.

Holton, W., Dunagan, H. 2010. Data processing summary: Cosco Busan shoreline and eelgrass habitats. http://nrm.dfg.ca.gov/FileHandler.ashx?DocumentID=36945 Last accessed January 28, 2016

Incardona J.P., Vines, C.A., Anulacion, B.F., Baldwin, D.H., Day, H.L., French, B.L., Labenia, J.S., Linbo, T.L., Myers, M.S., Olson, O.P., Sloan, C.A., Sol, S., Griffin, F.J., Menard, K., Morgan, S.B., West, J.E., Collier, T.K., Yitalo, G.M., Cherr, G.N., Scholz, N.L. 2012. Unexpectedly high mortality in Pacific herring embryos exposed to the 2007 Cosco Busan oil spill in San Francisco Bay. Proc. Natl. Acad. Sci. 109, E51-E58

Jackson, J.B.C., Cubit, J.D., Keller, B.D., Batista, V., Burns, K., Caffey, H.M., Caldwell, R.L., Garrity, S.D., Getter, C.D., Gonzalez, C., Guzman, H.M., Kaufmann, K.W., Knap, A.H., Levings, S.C., Marshall, M.J., Steger, R., Thompson, R.C., Weil, E. 1989. Ecological Effects of a Major Oil Spill on Panamanian Coastal Marine Communities. Science 243, 37-44.

Jacobs, R.P.W.M. 1980. Effects of the 'Amoco Cadiz' oil spill on the seagrass community at Roscoff with special reference to the benthic infauna. Mar. Ecol. Prog. Ser. 2, 207-212. 
Kenworthy, W.J., Durako, M.J., Fatemy, S.M.R., Valavi, H., Thayer, G.W. 1993. Ecology of seagrasses in northeastern Saudi Arabia one year after the Gulf War oil spill. Mar. Pollut. Bull. 27, 213-222.

Macinnis-Ng, C.M.O., Ralph, P.J. 2003. In situ impact of petrochemicals on the photosynthesis of the seagrass Zostera capricorni. Mar. Pollut. Bull. 46, 1395-1407.

Marshall, M.J. 1990. Subtidal seagrass communities. Pp. 261-286 in Long-term assessment of the oil spill at Bahia la Minas, Panama: interim report, Volume II. U.S. Department of the Interior, Minerals Management Service, publication number MMS 90-0031. Gulf of Mexico OCS Region, New Orleans.

Nadeau, R.J., Bergquist, E.T. 1977. Effects of the March 18, 1973 oil spill near Cabo Rojo, Puerto Rico on tropical marine communities. International Oil Spill Conference Proceedings: March 1977, Vol. 1977. 1, 535-538.

Nievales, M.F.J. 2008. Some structural changes of seagrass meadows in Taklong Island National Marine Reserve, Guimaras, Wester Visayas Philippines after an oil spill. The Nagisa Westpac Congress, 37-44. http://repository.kulib.kyoto-u.ac.jp/dspace/ bitstream/2433/144631/1/Spec9-04.pdf, last accessed 15 Feb 2016.

Peirano, A., Damasso, V., Montefalcone, M., Morri, C., Bianchi, C.N. 2005. Effects of climate, invasive species and anthropogenic impacts on the growth of the seagrass Posidonia oceanica (L.) Delile in Liguria (NW Mediterranean Sea). Mar. Pollut. Bull. $50,817-822$.

Phillips, R.C. 1984. The ecology of eelgrass meadows in the Pacific northwest: a community profile. U.S. Fish Wildl. Serv. USFWS/OBS-84/24. 85pp. 
Raimondi, P., Orr, D., Bell, C., George, M., Worden, S., Redfield, M., Gaddam, R., Anderson, L., Lohse, D. 2009. Determination of the extent and type of injury to rocky intertidal algae and animals one year after the initial spill (Cosco Busan): a report prepared for OSPR (California Fish and Game). https://nrm.dfg.ca.gov/ FileHandler.ashx?DocumentID=33648. Last accessed February 23, 2016.

Ralph, P.J., Burchett, M.D. 1998. Impact of petrochemicals on the photosynthesis of Halophila ovalis using chlorophyll fluorescence. Mar. Pollut. Bull. 36, 429-436.

Ralph, P.J., Gademann, R. 2005. Rapid light curves: A powerful tool to assess photosynthetic activity. Aquat. Bot. 82, 222-237.

Rützler, K., Sterrer, W. 1970. Oil pollution: Damage observed in tropical communities aliong the Atlantic seaboard of Panamá. Bioscience. 20, 222-224.

Sandulli, R., Bianchi, C.N., Cocito, S., Morri, C., Peirano, A., Sgorbini, S. 1998. An experience of 'baslisage' in monitoring the effects of the Haven oil spill on some Ligurian Posidoina oceanic meadows. Oebalia 24:3-15.

Sasil-Orbita M.L., Mukai, H. 2006. A comparative study of the photosynthetic activity among three temperate seagrass species in northern Japan. Mar. Ecol. 27, 388-396.

Scarlett, A., Galloway, T.S., Canty, M., Smith, E.L., Nilsson, J., Rowland, S.J. 2005. Comparative toxicity of two oil dispersants, superdispersant- 25 and corexit 9527 , to a range of coastal species. Environ. Toxicol. Chem. 24, 1219-1227.

Short, F.T., Burdick, D.M., Kaldy, J.E. 1995. Mesocosm experiments quantify the effects of eutrophication on eelgrass, Zostera marina. Limnol. Oceanogr. 40, 740-749. 
Silliman, B.R., Van De Koppel, J., McCoy, M., Diller, J., Kasozi, G.N., Earl, K., Adams, P.N., Zimmerman, A.R. 2012. Degradation and resilience in Louisiana salt marshes after the BP-Deepwater Horizon oil spill. Proc. Nat. Acad. Sci. 109, 11234-11239.

StatSoft Inc. 2003. STATISTICA (data analysis software system), version 6.1 series 0603c.

Taylor, E., Reimer, D. 2008. Oil persistence on beaches in Prince William Sound - A review of SCAT surveys conducted from 1989 to 2002. Mar. Pollut. Bull. 56, $458-474$.

Thorhaug, A., Marcus, J. 1987. Oil spill clean-up: The effect of three dispersants on three subtropical/tropical seagrasses. Mar. Pollut. Bull. 18, 124-126.

Thorhaug, A., Marcus, J., Booker, F. 1986. Oil and dispersed oil on subtropical and tropical seagrasses in laboratory studies. Mar. Pollut. Bull. 17, 357-361.

Thorhaug, A., Miller, B., Jupp, B., Booker, F. 1985. Effects of a variety of impacts on seagrass restoration in Jamaica. Mar. Pollut. Bull. 16, 355-360.

Tomlinson, P.B. 1974. Vegetative morphology and meristems dependence - the foundation of productivity in seagrasses. Aquaculture 4, 107-130.

Walz H. 1998. Underwater fluorometer diving-PAM Handbook of Operations. Heinz Walz GmbH, Effeltrich, Germany. 104p.

Wilson, K.G., Ralph, P.J. 2008. A comparison of the effects of Tapis crude oil and dispersed crude oil on subtidal Zostera capricorni. International Oil Spill Conference Proceedings: May 2008, Vol. 2008. 1, 859-864. 
Zaban, C., Grosholz, T., Attoe, S. 2009. Sublethal effects of the November 2007 Cosco Busan oil spill on native oysters. Report to California Department of Fish and Game. http://nrm.dfg.ca.gov/FileHandler.ashx?DocumentID=33649 . Last accessed January $28,2016$.

Zieman, J.C., Orth, R.J., Phillips, R.C., Thayer, G.W., A. Thorhaug, A. 1984. The effects of oil on seagrass ecosystems. Pages 37-64 in Cairns, J., Buikema, A.L. (Eds.) Restoration of habitats impacted by oil spills. Butterworth Publishers, Boston, MA.

Zimmerman, R.C., Reguzzoni, J.L., Wyllie-Echeverria, S., Josselyn, M., Alberte, R.S. 1991. Assessment of environmental suitability for growth of Zostera marina L. (eelgrass) in San Francisco Bay. Aquat. Bot. 39, 353-366. 


\section{Figures and Tables}

Fig. 1. Eelgrass sites surveyed following the Cosco Busan oil spill and location of the spill site (gray circle) in San Francisco Bay. Site abbreviations: PSP, Point San Pablo; PO, Point Orient; CC, Cozy Cove; KB, Keller Beach; EV, Emeryville; CB, Crown Beach; BF, Bay Farm Island; PC, Paradise Cove; KC, Keil Cove; AI, Angel Island; HC, Horseshoe Cove.

Fig. 2. Mean ( \pm 1 S.E.) vegetative shoot density $\mathrm{m}^{-2}$ at sites pre-spill and post-spill $(\mathrm{n}=10$ per site). Not all sites visited post-spill had been previously investigated. Post-spill sites arranged by oiling category. For post-spill sites; grayscale coloring reflects oiling status: hollow bars = no oil (sites PO, PSP), light gray bars = very lightly oiled (sites BF, CB, PC), gray = lightly oiled (site AI), dark gray = moderately oiled (sites CC, EV, HC, KB) solid black $=$ heavily oiled (sites $\mathrm{KB} \mathrm{KC}$ ). Asterisks $(*)$ below the site name indicates a significant $(\mathrm{p}<0.05)$ difference in shoot densities as compared with those pre-spill.

Fig. 3. Mean rhizome fractional growth of four most recent complete nodes (node $1=<$ 10 days old, node $4=$ approximately 60 days old) at each site by oiling categories $(n=10$ per site). Vertical reference line denotes approximate time of spill. No rhizome samples were collected from $\mathrm{CB}$ and $\mathrm{HC}$ due to low plant density.

Fig. 4. Mean ( \pm 1 S.E) effective quantum yield $\left(\Delta \mathrm{F} / \mathrm{F}_{\mathrm{m}}{ }^{\prime}\right)$ of Zostera marina leaves. Lower-case letters indicate differences among categories detected by post-hoc statistical comparisons. 
Fig. 1.

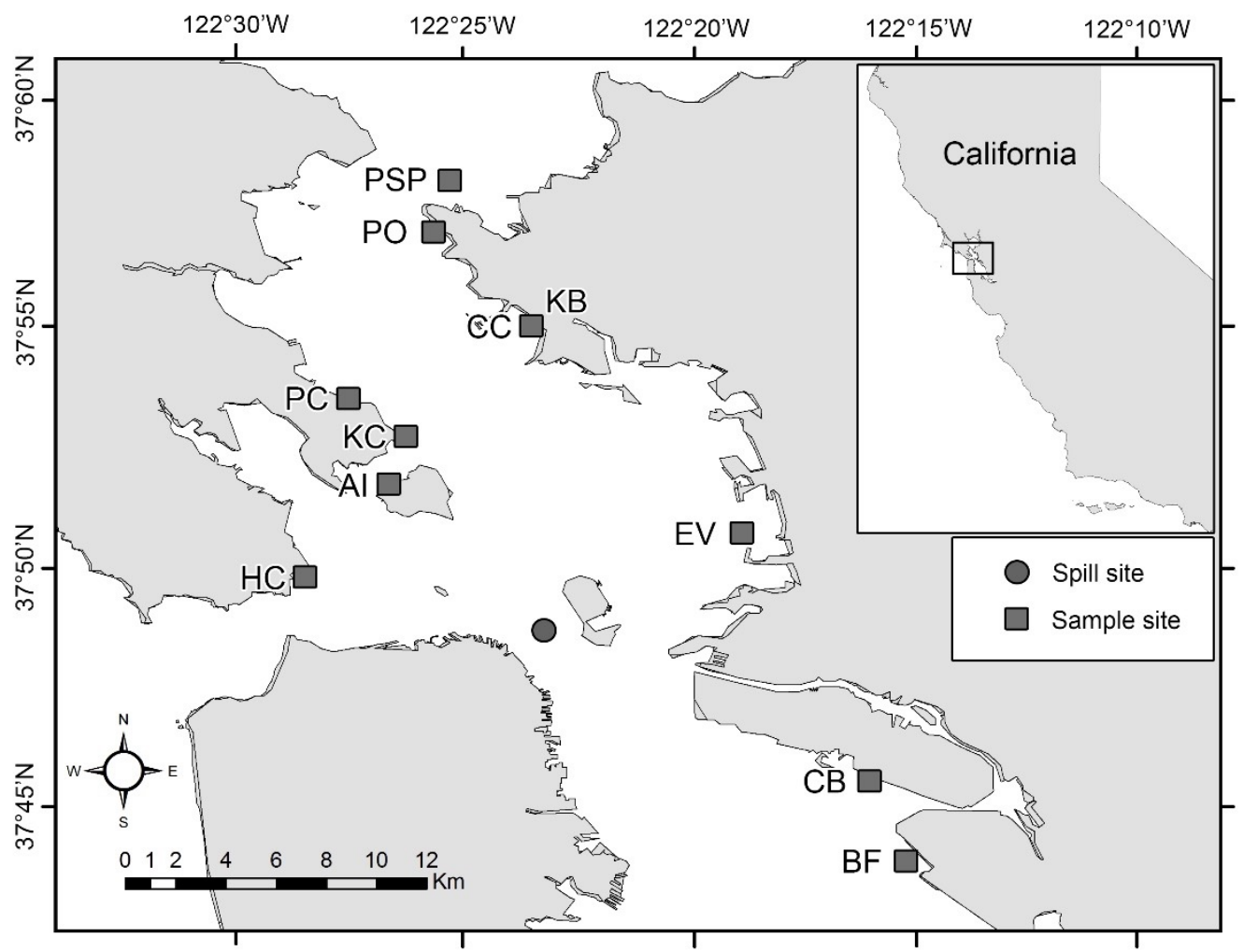




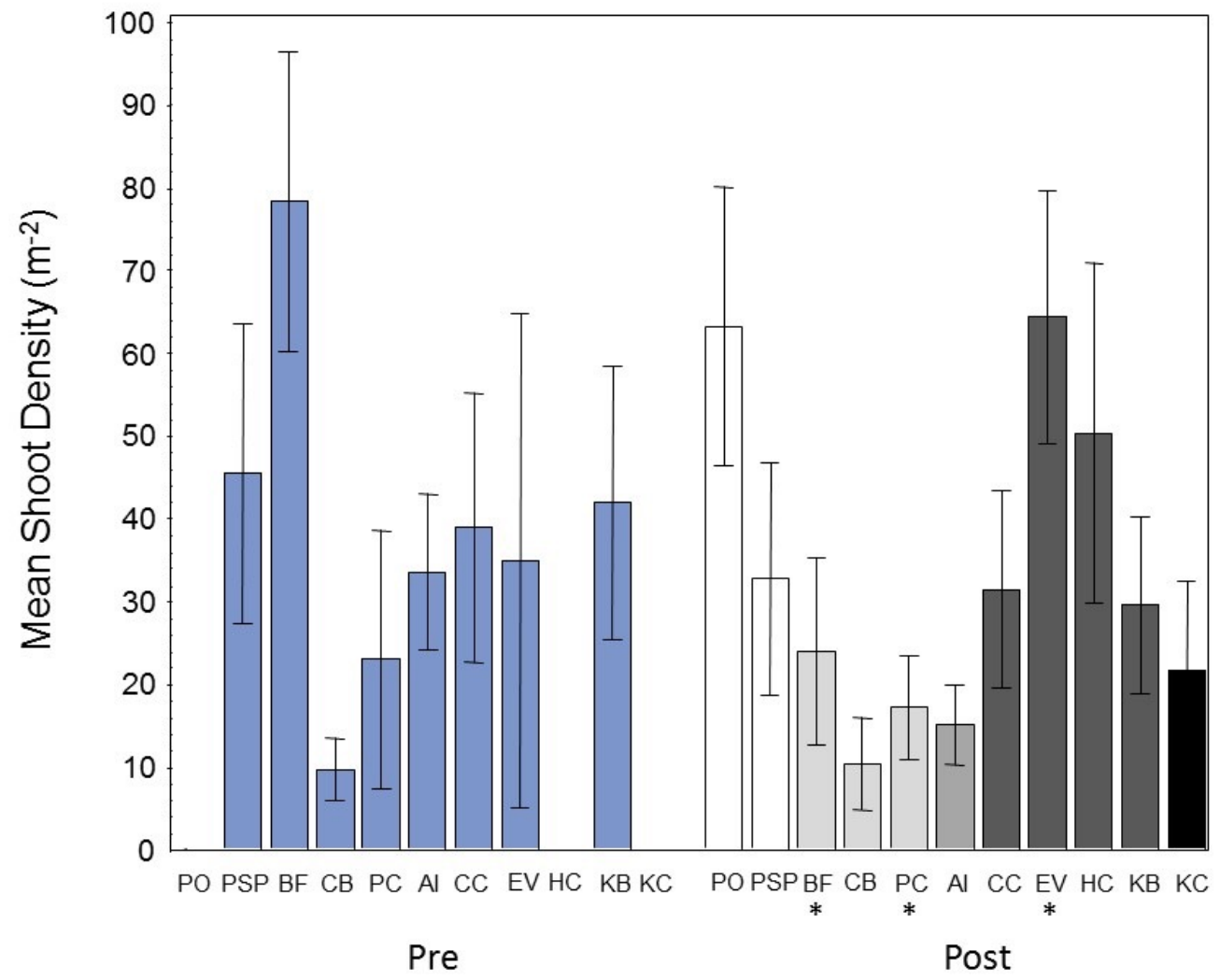

Fig. 2. 
Fig. 3.
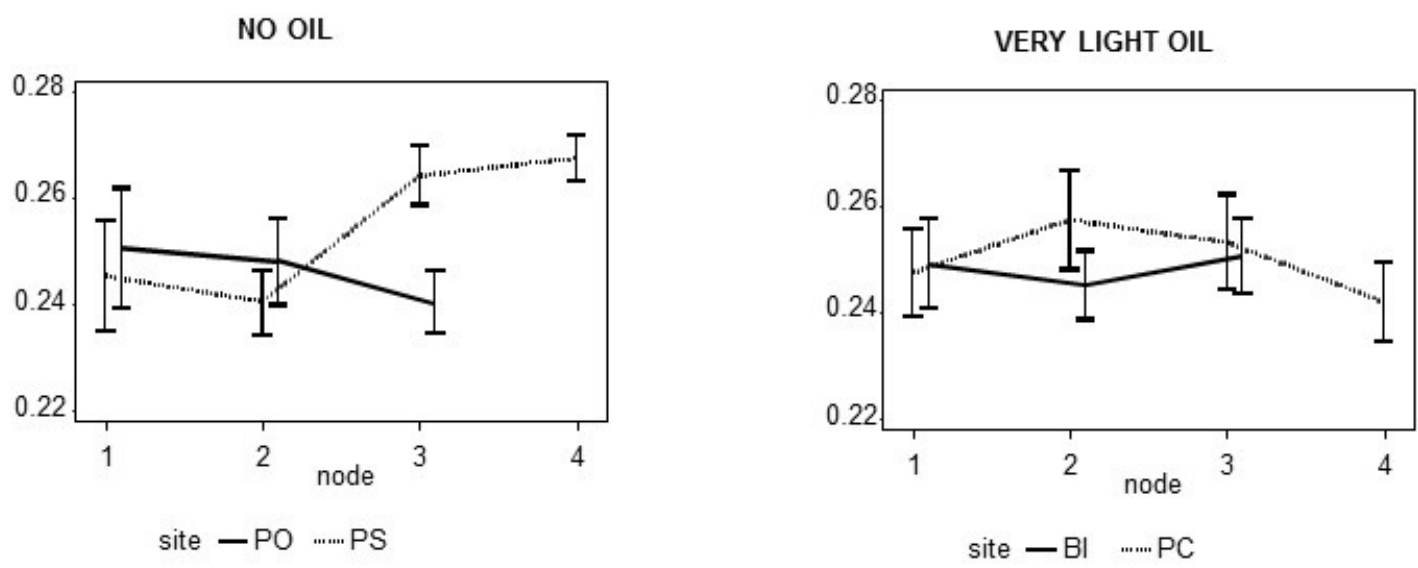

LIGHT OIL

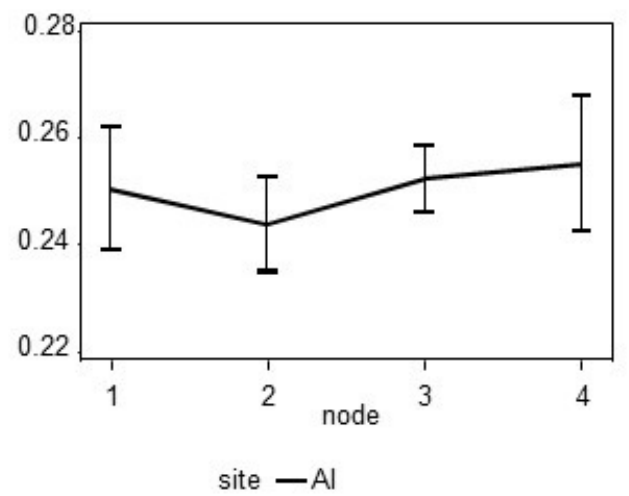

HEAVY OIL

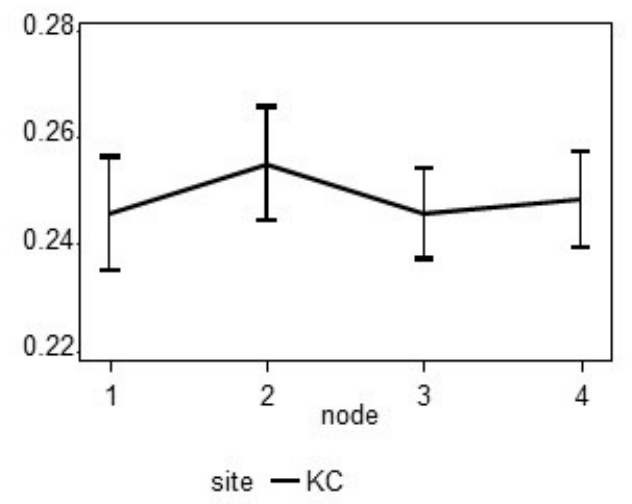

MODERATE OIL

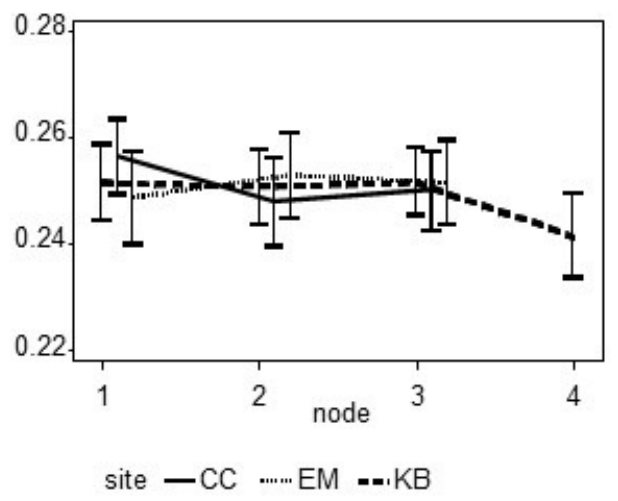


Fig. 4.

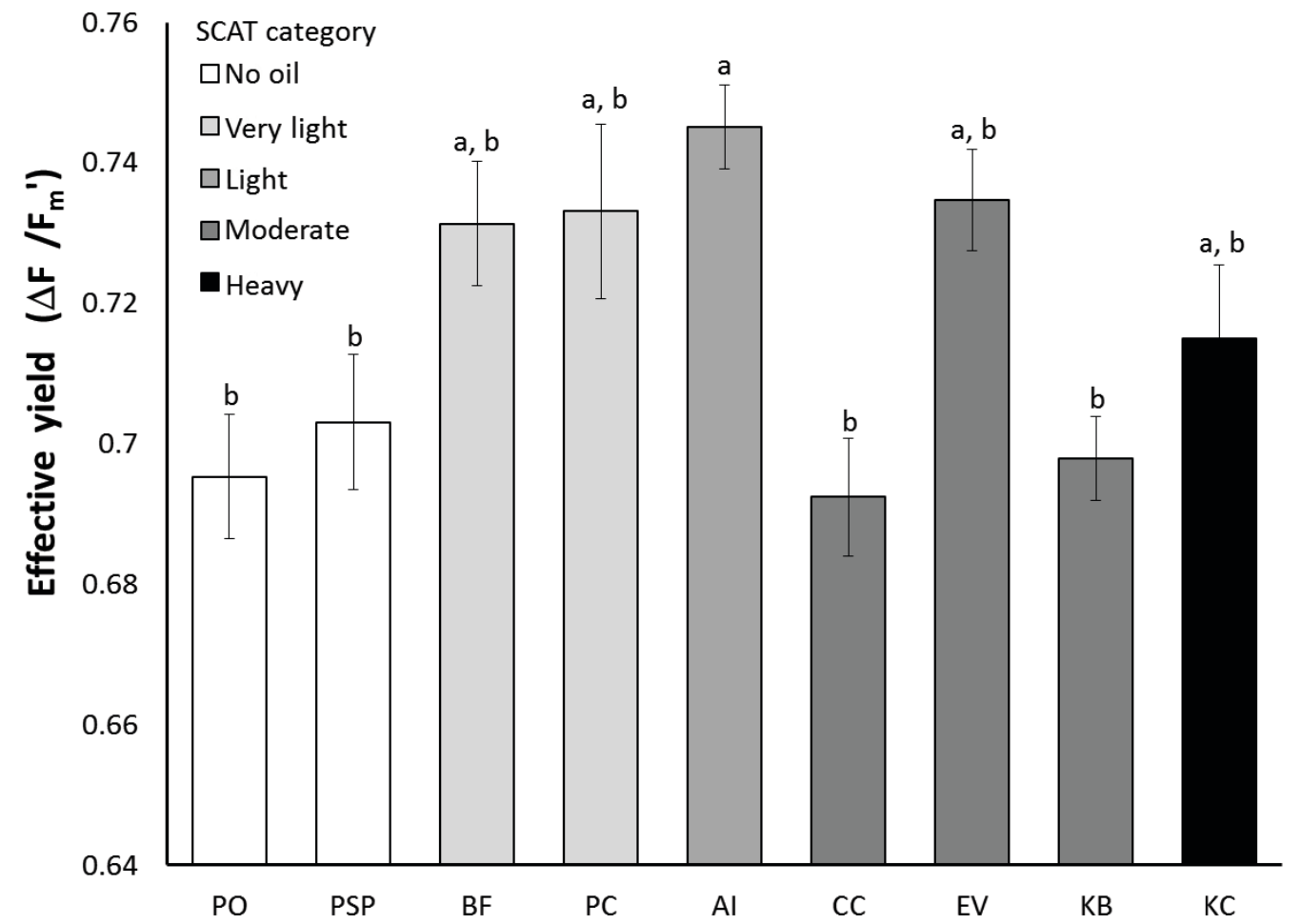


Table 2. Sample sites from post-spill eelgrass survey, conducted November 2007.

\begin{tabular}{lllll} 
Site & $\begin{array}{l}\text { SCAT } \\
\text { Oiling } \\
\text { Status }\end{array}$ & $\begin{array}{l}\text { SG } \\
\text { Surface } \\
\text { Oil }\end{array}$ & $\begin{array}{l}\text { SG } \\
\text { Subsurface } \\
\text { Oil }\end{array}$ & $\begin{array}{l}\text { Oil of } \\
\text { Surrounding } \\
\text { Area }\end{array}$ \\
\hline PO & No Oil & none & none & none \\
PSP & No Oil & none & none & none \\
BF & Very Light & none & none & none \\
CB & Very Light & none & none & none \\
PC & Very Light & nd & nd & none \\
AI & Light & nd & nd & tar balls on boulder \\
CC & Moderate & none & none & none \\
EV & Moderate & none & none & none \\
HC & Moderate & sheen & none & oil mat on shoreline \\
KB & Moderate & none & none & post-cleanup \\
KC & Heavy & nd & nd & \\
& & & & \\
\hline
\end{tabular}

Notes: Surface oil, oiling observed on sediment or plant surface within seagrass meadow; Subsurface oil, oil released when sediment surface disturbed within seagrass meadow; nd =no data available. 
Table 3. Shoot density comparison by site using post-hoc sequential Bonferroni comparison (-, non-significant; *, significant difference where adjusted $\alpha=0.05$ ).

\begin{tabular}{|c|c|c|c|c|c|c|c|c|c|c|c|c|}
\hline & \multicolumn{2}{|c|}{ no oil } & \multicolumn{3}{|c|}{ very light } & \multirow{2}{*}{$\begin{array}{c}\text { light } \\
\text { AI }\end{array}$} & \multicolumn{4}{|c|}{ moderate } & \multirow{2}{*}{$\begin{array}{c}\text { heavy } \\
\mathrm{KC}\end{array}$} \\
\hline & & PO & PSP & $\mathrm{BF}$ & $\mathrm{CB}$ & PC & & $\mathrm{CC}$ & EV & $\mathrm{HC}$ & KB & \\
\hline \multirow[t]{2}{*}{ no } & $\mathrm{PO}$ & & & & & & & & & & & \\
\hline & PSP & $*$ & & & & & & & & & & \\
\hline ve & $\mathrm{BF}$ & * & - & & & & & & & & & \\
\hline ry & $\mathrm{CB}$ & $*$ & $*$ & - & & & & & & & & \\
\hline $\begin{array}{l}\text { lig } \\
\text { ht }\end{array}$ & $\mathrm{PC}$ & $*$ & - & - & - & & & & & & & \\
\hline $\begin{array}{l}\text { lig } \\
\text { ht }\end{array}$ & AI & $*$ & - & - & - & - & & & & & & \\
\hline $\mathrm{m}$ & $\mathrm{CC}$ & $*$ & - & - & $*$ & - & $*$ & & & & & \\
\hline \multirow{2}{*}{ od } & EV & - & $*$ & $*$ & $*$ & $*$ & $*$ & $*$ & & & & \\
\hline & $\mathrm{HC}$ & - & - & $*$ & $*$ & $*$ & $*$ & - & - & & & \\
\hline $\begin{array}{l}\text { era } \\
\text { te }\end{array}$ & KB & $*$ & - & - & $*$ & - & - & - & $*$ & * & & \\
\hline he & $\mathrm{KC}$ & & & & & & & & & & & \\
\hline $\begin{array}{l}\text { av } \\
\mathrm{y}\end{array}$ & & $*$ & - & - & - & - & - & - & $*$ & $*$ & - & \\
\hline
\end{tabular}


Table 4. Analysis of approximately 60 days of rhizome growth (4 complete internodes).

\begin{tabular}{|c|c|c|c|}
\hline $\begin{array}{c}\text { Oiling } \\
\text { status }\end{array}$ & Site & $\mathrm{P}$ & $\begin{array}{c}\text { Internode expansion: } \\
\text { (old to young) }\end{array}$ \\
\hline \multirow{2}{*}{ no oil } & PO & 0.0164 & Increasing \\
\cline { 2 - 4 } & PSP & $<0.001$ & Decreasing \\
\hline \multirow{2}{*}{ very light } & $\mathrm{BF}$ & 0.0003 & Decreasing \\
\cline { 2 - 4 } & $\mathrm{PC}$ & 0.0069 & Decreasing \\
\hline \multirow{2}{*}{ light } & $\mathrm{AI}$ & 0.0025 & Decreasing \\
\hline \multirow{2}{*}{ moderate } & $\mathrm{CC}$ & 0.4 & Uniform \\
\cline { 2 - 4 } & $\mathrm{EV}$ & 0.5098 & Uniform \\
\cline { 2 - 4 } & $\mathrm{KB}$ & 0.0068 & Increasing \\
\hline heavy & $\mathrm{KC}$ & 0.0779 & Uniform \\
\hline
\end{tabular}


Table 5. Rapid light curve parameters (average $\pm \mathrm{SE}$ ) for Zostera marina at sites surveyed for oiling in San Francisco Bay.

\begin{tabular}{lllll} 
Site & SCAT Oiling & rETRm & $\alpha$ & $\mathbf{E}_{\mathbf{k}}$ \\
\hline PO & none & $67.7 \pm 1.3$ & $0.386 \pm 0.003$ & $175.7 \pm 4.2$ \\
PSP & none & $73.9 \pm 2.6$ & $0.389 \pm 0.003$ & $190.3 \pm 7.1$ \\
BF & very light & $56.6 \pm 3.3$ & $0.389 \pm 0.009$ & $145.9 \pm 8.7$ \\
PC & very light & $46.4 \pm 2.2$ & $0.370 \pm 0.010$ & $126.2 \pm 7.0$ \\
AI & light & $55.7 \pm 2.1$ & $0.365 \pm 0.010$ & $155.0 \pm 6.8$ \\
CC & moderate & $56.6 \pm 2.4$ & $0.386 \pm 0.007$ & $145.9 \pm 4.5$ \\
EV & moderate & $53.6 \pm 3.0$ & $0.370 \pm 0.015$ & $147.3 \pm 11.1$ \\
KB & moderate & $57.0 \pm 1.9$ & $0.392 \pm 0.007$ & $146.2 \pm 7.0$ \\
KC & heavy & $47.5 \pm 1.7$ & $0.364 \pm 0.010$ & $131.0 \pm 3.6$
\end{tabular}

